\title{
A Cytopathological and Histopathological Correlation Study of Benign and Malignant Paediatric Age Group Tumour
}

\author{
Mukesh Kumar Khinchi ${ }^{*}$, Manish Kumar Singhal ${ }^{1}$, Sangita Sehgal2 ${ }^{2}$ Rachna Agrawal ${ }^{3}$, \\ Ashish Bagaria ${ }^{1}$, Vinod Kumari ${ }^{4}$, Alpana Jain ${ }^{3}$, Vijayta Singh ${ }^{5}$ \\ ${ }^{1}$ Assistant Professor, ${ }^{2}$ Associate Professor, ${ }^{3}$ Senior Demonstrator, ${ }^{4}$ Medical Officer, ${ }^{5}$ Senior Resident, \\ Department of Pathology, SMS Medical College, Jaipur, Rajasthan, India.
}

\begin{abstract}
Objective: Cancer is a rarity in childhood. It is a major cause of death in pediatric age group. Present study was aimed to evaluate role of cytology in diagnosis of malignancy in pediatric age group and correlate these finding with Histopathology.

Method: In present study, 100 cases of pediatric malignancy were studied under the age group 0-14 years in our series. Cytosmears made from material obtained by FNAC. In neuromalignant cases cytosmears were prepared by squash technique. Histopathology was done on lump removed by surgery. Stained by rapid papanicoloau techniques, hematoxylin and eosin, and May grunwald giemsa stains. For histopathology, routine Hematoxylin and Eosin staining was done.

Result: Out of 100 cases, satisfactory aspiration was obtained in 87 (87\%). Out of these, 87 cytosmears, the diagnosis was consistent with histopathology in 70 cases and not consistent in 17 cases. Therefore, an accuracy rate of $80.4 \%$ was obtained. Commonest malignancy was of kidney, mainly wilm's tumour (25\%). Lymphoma was second common (22\%) followed by soft tissue sarcoma (18\%).

FNAC is feasible, rapid and inexpensive first approach in evaluation of cases of pediatric tumour but cytological diagnosis on FNAC is not a substitute for the histological
\end{abstract}

\section{INTRODUCTION}

Although cancer is a rarity in childhood; It is a major cause of death in pediatric age group. Its insidious onset, emotional \& psychological impact, lethal nature and increasing prospects of cure due to advances in diagnostic pathology, surgery, radiotherapy and chemotherapy; make it one of the major challenging aspects.

One third of childhood cancer is due to leukaemia, Lymphomas, brain tumours and wilm's tumor account for the other more frequent types. The frequency of different pediatric tumours varies with age and this may be a useful diagnostic pointer. The majority of cases of embryonal tumours (Neuroblastoma, Nephroblastoma, hepatoblastoma, medulloblastoma, retinoblastoma) occur in children less than 5 years old, reflecting the origin of embryonal tumours from immature tissues. Lymphomas, bone tumours \& germ cell tumours occur more frequently in the 10-12 years age group (Pratt.,1985). ${ }^{1}$ diagnosis on tissue section. In 0-5 yrs. age group, Kidney tumours were the commonest malignancy. In 5-10 yrs. age group commonest were lymphomas and in 10-14 yrs. age group soft tissue tumours formed the main type. Male preponderance was seen in all malignancies except malignant teratoma, gonadal tumours and neuroblastoma.

Keywords: Wilm's tumours, Lymphoma, FNAC.

\section{${ }^{*}$ Correspondence to:}

Dr. Mukesh Kumar Khinchi

Assistant Professor,

Department of Pathology,

SMS Medical College,

Jaipur, Rajasthan, India.

\section{Article History:}

Received: 15-10-2016, Revised: 03-11-2016, Accepted: 28-11-2016

\begin{tabular}{|l|c|}
\hline \multicolumn{2}{|c|}{ Access this article online } \\
\hline $\begin{array}{l}\text { Website: } \\
\text { www.ijmrp.com }\end{array}$ & Quick Response code \\
\hline DOI: & \\
10.21276/ijmrp.2016.2.6.036 & \\
\hline
\end{tabular}

For the lab diagnosis, various procedures like cytopathology, histopathology have been used since past with variable success rates. Histopathologists have contributed to the remarkable progress both directly by identifying new tumour entities with important therapeutic and prognostic implications \& indirectly by submitting material to multicenter studies.

The present study is undertaken with an aim to evaluate the role of cytopathology and subsequently histopathology in diagnosis of tumours in pediatric age group. In Cytopathology diagnosis is made by study of cells and tissue fragments collected by needle aspiration is made of superficial or deep masses; and by squash smears where cytosmears are prepared by crushing tiny fragment of freshly removed surgical biopsy material. In histopathology, this surgical biopsy material is processed into paraffin blocks and then studied in $\mathrm{H}$ \& $\mathrm{E}$ smears. The cytological findings are then correlated with histopathological appraisal. 
This study is carried on various malignancies arising in pediatric age group (0-14 years) obtained by fine needle aspiration. Cytosmears prepared by squash in neuromalignant cases. Biopsy from lump surgical removed in cases of solid tumours.

\section{MATERIALS AND METHODS}

This study was done in SMS Medical College, Jaipur in Department of Patholgy. This study was carried on various pediatric malignancy (0-14 years). Cytology smear is immediately fixed in $95 \%$ ethyl alcohol for a minimum period of 15 minutes and stained by rapid papanicoloau techniques, hematoxylin and eosin, and may grunwald giemsa stains. For histopathology; routine Hematoxylin and Eosin staining was done.

Hematoxylin crystals: $1 \mathrm{gm}$

Distilled water: $100 \mathrm{ml}$

Sodium iodate: $0.2 \mathrm{gm}$

Ammonium potassium alum: $50.0 \mathrm{gm}$

Citric acid: $1.0 \mathrm{gm}$

Chloral hydrate: $50.0 \mathrm{gm}$

\section{Cytosmears Made By Squash Technique}

The method of squash technique adopted is that of Russel et al. $(1937)^{2}$. The biopsy material removed surgically is obtained. A small piece of biopsy material is cut with the help of a dissecting forceps and a scalpel. Cytosmear are made by placing the small tissue fragment on one slide and smearing it with gentle pressure using another slide. In this manner, a series of imprint smears are made. Smears are fixed immediately in 95\% alcohol and stained by haematoxylin and eosin and papanicolau's stain.

\section{OBSERVATIONS}

In present study, 100 cases of pediatric malignancies are studied under the age group 0-14 years. The following observations were made. Total cases studied on cytological smears were 100. Failed applications were 13 , Adequate aspirations were 87 , out of these 87 , constituent with histopathology were 70 , non-consitient with histopathology were 17 , accuracy of FNAC $80.4 \%$ failure rate $19.6 \%$.

Commonest malignancy was kidney, mainly Wilm's tumours $(25 \%)$ and a case of clear sarcoma of infancy. Lymphoma was at second place $(22 \%)$ and soft tissue tumor $(18 \%)$ at third place out of which majority were Ewing's sarcoma. Brain Tumours Constituted $12 \%$, Eye tumours $9 \%$, Gonadal Tumours 5\%, Neuroblastoma, Bone tumours and malignant teratoma accounted for $3 \%$ each.

In 0-5 yrs. age group, Kidney tumours were the commonest malignancy. In 5-10 yrs. age group commonest were lymphomas and in 10-14 yrs. age group soft tissue tumours formed the main type. Male preponderance was seen in all malignancies except malignant teratoma, gonadal tumours and neuroblastoma.

In 0-5 year age group, out of 22 cases 19 were cytologically diagnostic for Wilm's tumour while three were negative. Therfore $86.3 \%$ cases could be correlated. In $5-10$ year $100 \%$ correlation was obtained. Overall a correlation between cytology and histopathology was seen in $88 \%$ cases of wilm's tumour.

Table 1: Incidence of different type of malignancies

\begin{tabular}{lcc}
\hline Malignancy types & No. of patients & Percentage (\%) \\
\hline Kidney tumour & 25 & $25 \%$ \\
Lymphoma & 22 & $22 \%$ \\
Soft tissue tumours & 18 & $18 \%$ \\
Brain tumours & 12 & $12 \%$ \\
Eye Tumours & 9 & $9 \%$ \\
Gonadal tumours & 5 & $5 \%$ \\
Neuroblastoma & 3 & $3 \%$ \\
Bone tumours & 3 & $3 \%$ \\
Malignant Teratoma & 3 & $3 \%$ \\
Liver Tumours & 0 & $0 \%$ \\
Total & 100 & 100 \\
\hline
\end{tabular}

Table 2: Age wise Distribution of Malignancies

\begin{tabular}{lcc}
\hline Age group (years) & No. of Patients & Percentage \\
\hline $\mathbf{0 - 5}$ & 54 & $54 \%$ \\
$\mathbf{5}-10$ & 33 & $33 \%$ \\
$10-14$ & 13 & $13 \%$ \\
Total & 100 & 100 \\
\hline
\end{tabular}

Table 3: Sex wise Distribution of Malignancies

\begin{tabular}{lcccc}
\hline Malignant Cases & \multicolumn{2}{c}{ MALES } & \multicolumn{2}{c}{ FEMALES } \\
\cline { 2 - 5 } 100 & Number & Percentage & Number & Percentage \\
\hline
\end{tabular}


Table 4: Age Incidence in different Malignancies

\begin{tabular}{lcccc}
\hline Malignancy types & No. of patients & $\mathbf{0 - 5} \mathbf{y r}$. & $\mathbf{5 - 1 0} \mathbf{y r}$. & $\mathbf{1 0 - 1 4} \mathbf{y r}$. \\
\hline Kidney tumour & 25 & 22 & 3 & - \\
Lymphoma & 22 & 7 & 11 & 4 \\
Soft tissue tumours & 18 & 5 & 8 & 5 \\
Brain tumours & 12 & 3 & 5 & 4 \\
Eye Tumours & 9 & 8 & 1 & - \\
Gonadal tumours & 5 & 4 & 1 & - \\
Neuroblastoma & 3 & 3 & - & - \\
Bone tumours & 3 & 1 & 2 & - \\
Malignant Teratoma & 3 & 1 & 2 & - \\
Liver Tumours & 0 & - & - & - \\
Total & 100 & 55 & 34 & 13 \\
\hline
\end{tabular}

Table 5: Different Types of Kidney Tumours

\begin{tabular}{lcc}
\hline Kidney Tumours & No. of Pateints & Percentage \\
\hline Wilm's Tumour & 24 & $96 \%$ \\
Clear Cell Sarcoma of infancy & 1 & $04 \%$ \\
Total & 25 & $100 \%$ \\
\hline
\end{tabular}

Table 6: Accuracy of Needle Aspiration in Kidney tumours

\begin{tabular}{|c|c|c|c|c|c|}
\hline \multirow[t]{2}{*}{ Wilm's Tumours } & \multirow{2}{*}{$\begin{array}{l}\text { Total no. } \\
\text { of cases }\end{array}$} & \multicolumn{2}{|c|}{ Cytology } & \multirow{2}{*}{$\begin{array}{l}\text { Histopathologically } \\
\text { Positive cases }\end{array}$} & \multirow{2}{*}{$\begin{array}{c}\text { No. Of cases correlated } 8 \\
\text { percentage }\end{array}$} \\
\hline & & $\begin{array}{c}\text { Positive } \\
\text { Cases }\end{array}$ & $\begin{array}{l}\text { Negative } \\
\text { cases }\end{array}$ & & \\
\hline $0-5 \mathrm{yrs}$ & 22 & 19 & 3 & 22 & $19(86.3 \%)$ \\
\hline $5-10 \mathrm{yrs}$. & 3 & 3 & - & 3 & $3(100 \%)$ \\
\hline $10-15 \mathrm{yrs}$. & - & - & - & - & \\
\hline Total & 25 & 22 & 3 & 25 & $22(88 \%)$ \\
\hline
\end{tabular}

Table 7: Lymphoma Cases

\begin{tabular}{lcc}
\hline Lymphoma types & No. of Patients & Percentage \\
\hline Hodgkin's disease & 12 & $54.5 \%$ \\
Non-Hodgkin's Disease & 10 & $45.5 \%$ \\
Total & 22 & $100 \%$ \\
\hline
\end{tabular}

Table 8: Accuracy of FNAC in cases of Hodkin's disease

\begin{tabular}{|c|c|c|c|c|c|c|}
\hline \multirow{2}{*}{$\begin{array}{l}\text { Age Gr. } \\
\text { (in yrs.) }\end{array}$} & \multirow{2}{*}{$\begin{array}{l}\text { Total no. } \\
\text { of cases }\end{array}$} & \multicolumn{3}{|c|}{ Cytology } & \multirow{2}{*}{$\begin{array}{l}\text { Histo. Positive } \\
\text { for Hodkin's }\end{array}$} & \multirow{2}{*}{$\begin{array}{l}\text { No. of cases } \\
\text { correlated }\end{array}$} \\
\hline & & $\begin{array}{l}\text { Diagnostic } \\
\text { of Hodkin's }\end{array}$ & $\begin{array}{c}\text { Reactive } \\
\text { hyper-plasia }\end{array}$ & Inadequate & & \\
\hline $0-5$ & 4 & 3 & - & 1 & 4 & 3 \\
\hline 5-10 & 4 & 2 & 2 & - & 4 & 2 \\
\hline \multirow[t]{2}{*}{$10-14$} & 4 & 2 & - & 2 & 4 & 2 \\
\hline & 12 & $7(58.3 \%)$ & $2(16.6 \%)$ & $3(25 \%)$ & 12 & $7(58.3 \%)$ \\
\hline
\end{tabular}

Table 9: Accuracy of FNAC in cases of NHL

\begin{tabular}{|c|c|c|c|c|c|c|}
\hline \multirow{2}{*}{$\begin{array}{l}\text { Age Gr. } \\
\text { (in yrs.) }\end{array}$} & \multirow{2}{*}{$\begin{array}{l}\text { Total no. } \\
\text { of cases }\end{array}$} & \multicolumn{3}{|c|}{ Cytology } & \multirow{2}{*}{$\begin{array}{l}\text { Histo. Positive } \\
\text { for NHL }\end{array}$} & \multirow{2}{*}{$\begin{array}{l}\text { No. of cases } \\
\text { correlated }\end{array}$} \\
\hline & & $\begin{array}{c}\text { Diagnostic } \\
\text { of NHL }\end{array}$ & $\begin{array}{c}\text { Reactive } \\
\text { hyper-plasia }\end{array}$ & Inadequate & & \\
\hline $0-5$ & 2 & 1 & - & 1 & 4 & 1(33.3\%) \\
\hline $5-10$ & 8 & 6 & 1 & 1 & 4 & $5(71.4 \%)$ \\
\hline \multirow[t]{2}{*}{$10-14$} & - & - & - & - & 4 & - \\
\hline & 10 & $7(70 \%)$ & $1(10 \%)$ & $2(20 \%)$ & 12 & $7(70 \%)$ \\
\hline
\end{tabular}




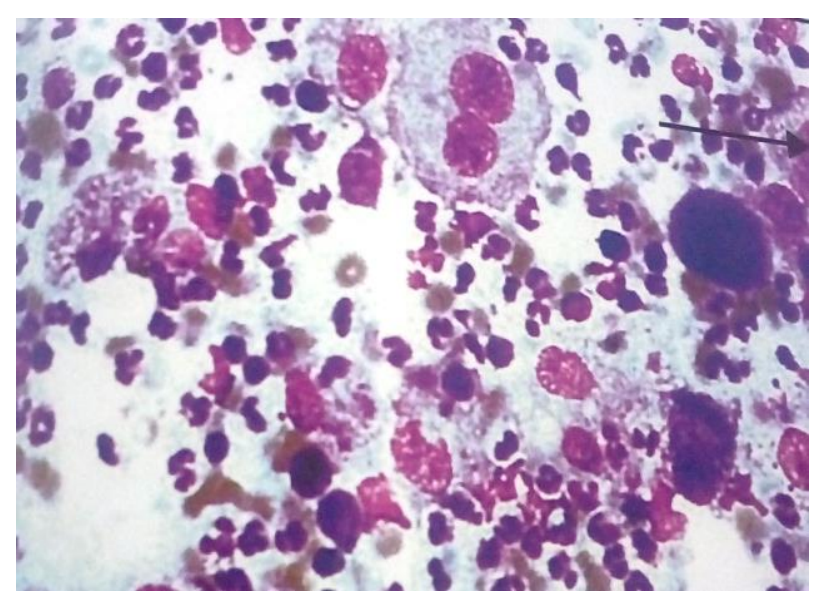

Fig 1: Hodgkin Lymphoma; Binuclear Reed Sternberg cells and mononuclear Hodgkin cells in a background of mainly small lymphocytes and granulocytes (MGG 100X)

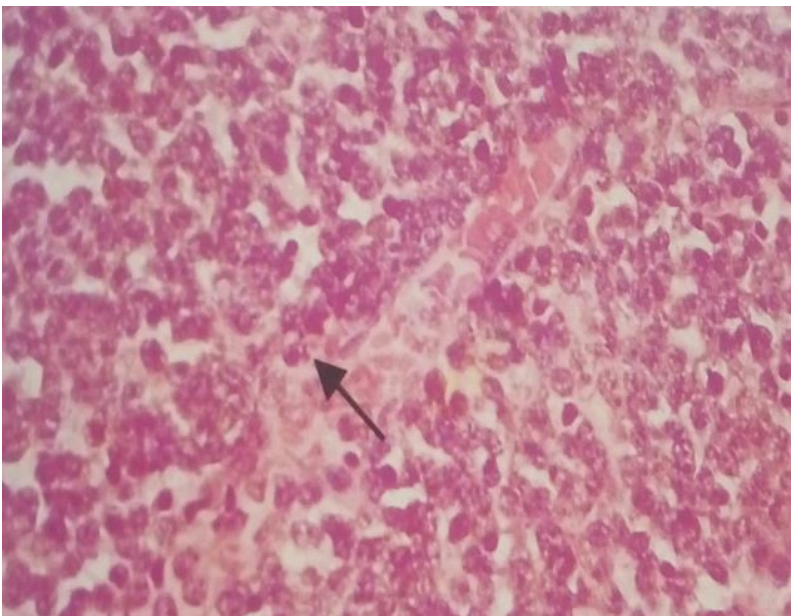

Fig 2: Medulloblastoma; Uniform malignant cell have very scanty cytoplasm and round or Ovoid basophilic vesicular with prominent nucleolus (H \&E 40X)

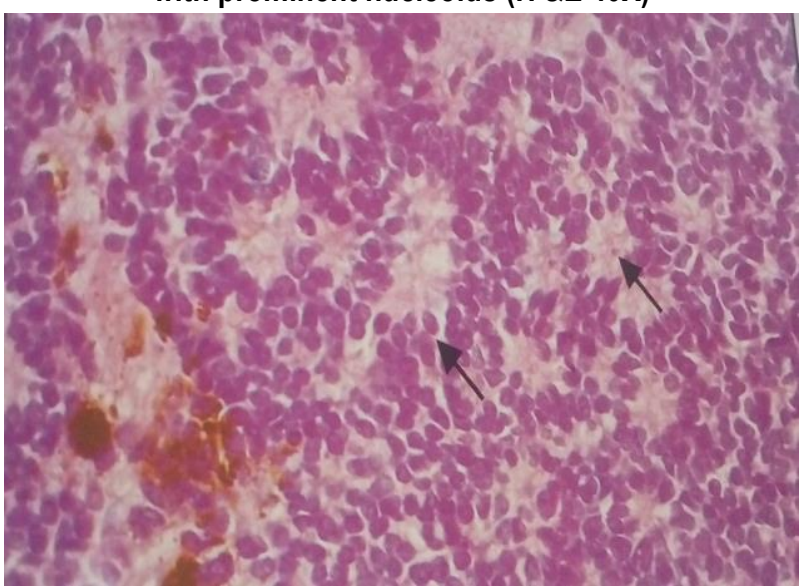

Fig 3: Retinoblastoma; Cells of uniform size and shape with scanty cytoplasm, nuclei are deeply basophilic and round or slightly ovoid. Rosette with central lumen full of eosinophilic fibrillary material (H \&E 40X)

Hodgkin's disease was found in $54.5 \%$ cases while nonHodgkin's constituted remaining $45.5 \%$. In $58.3 \%$ of cases, cytological findings correlated with histopathology, $16.6 \%$ cases were diagnosed a reactive hyperplasia while $25 \%$ smears were insufficient to conclude a diagnosis.

In $70 \%$ of cases, cytologically smears were diagnosed as $\mathrm{NHL}$ which was further confirmed on histopatholgy.
18 cases of soft tissue sarcoma are obtained showing 12 cases of Ewing sarcoma. In 8 cases cytology was diagnostic, in 2 cases round cell were seen. In 2 cases aspiration was insufficient.

12 cases of brain tumour were seen. Out of these 11 cases show medulloblastoma and one case diagnosed as Ependymoma. $91.6 \%$ correlation was seen in all cases studied, between smears prepared by squash method and histopatholgy. 9 cases of eye tumour were obtained showing $78 \%$ correlation with histopathology.

\section{DISCUSSION}

In present study, 100 cases of pediatric malignancy were studied under the age group 0-14 years. In our series, commonest malignancy was of kidney, mainly Wilm's tumour (25\%) and a clear sarcoma of infancy. Lymphomas were at second place $(22 \%)$. (Table 1) There was a preponderance of males being affected (Male:Female Ratio 2:3:1, Table-3). Majority of cases of embryonal tumours (Neuroblastoma, Nephroblastoma, Hepatoblastoma, Medulloblastoma, Retinoblastoma) were found to arise in 0-5 yrs are group, Lymphomas were more common in 5-10 yrs age group while bone tumour, soft tissue tumours and germ cell tumours were more commonly seen in 10-14 yrs. age group.

The results of fine needle aspiration cytology technique on comparison with histopathological findings, gave an accuracy rate of $80.4 \%$. This finding was comparable with the results of workers like taylor et al. (1984) 3 and layfield et al. (1991) ${ }^{4}$ who gave an accuracy rate of $76 \%$ and $81 \%$ respectively.

\section{Kidney Tumours}

Wilm's tumour is the most common childhood tumour of the kidney. Kidney tumours accounted for maximum number of cases $(25 \%)$. Our findings are comparable to the result obtained by workers like Alasio et al. $(1988)^{5}$ and Bezabih 6 whose accuracy rate varied from $76 \%$ - $95 \%$.

Most of the observations made in our series were similar to those of others. The aspirates were cellular with $79.1 \%$ cytosmears showing presence of blastemal cells which were small round cells with uniform hyperchromatic nuclei, $50 \%$ had presence of epithelial cells and $83.3 \%$ showed mesenchymal cells corresponding to those noted by Beckwith \& Palmer 7 .

\section{Lymphomas}

Hodgkin's disease was found in $54.5 \%$ cases while $\mathrm{NHL}$ constituted remaining $45.5 \%$. (Table- 8 ) In this study, in $58.3 \%$ cases, smears were diagnostic of hodgkin's lymphoma while $16.6 \%$ were false negative as the smear showed features of reactive hyperplasia while in $25 \%$ of smears the aspirates consisted of few atypical lymphoid cells which indicated a primary lymphoid neoplasm but were insufficient to conclude a diagnosis and required further histopathological study. Thus, accuracy rate was $58.3 \%$. This finding is in accordance with an accuracy rate of $66.6 \%$, reported by Nayer et al. $(1990)^{8}$.

Non-Hodgkin's Lymphoma was seen in $45.5 \%$ of cases. In present series, in $70 \%$ of cases FNAC smears were diagnosed as $\mathrm{NHL}$ giving an accuracy rate of $70 \%$. These observations were comparable with previous study like Nayar et al.(1990). ${ }^{8}$

\section{Soft Tissue Tumours}

In our series, 18 cases of soft tissue tumours were aspirated. Out of these, 12 cases (66.6\%) were diagnosed as Ewing's sarcoma, 2 as rhabdomyosarcoma and the other four cases were poorly 
differentiated sarcoma whose exact histogenesis could not be ascertained (Table-11). This finding was in accordance with the observations of Dahl and Ackerman et al. who reported an accuracy rate of $71.4 \%$.

\section{Brain Tumour}

12 cases of neuromalignant cases were diagnosed. There were $91.5 \%$ cases of medullablastoma and $8.3 \%$ cases of ependymoma.

Therefore an accuracy rate of $91.6 \%$ was achieved. This was comparable with the observations reported by following authors:

\begin{tabular}{lccc}
\hline Name of Author & Year & $\begin{array}{c}\text { No. of } \\
\text { cases }\end{array}$ & $\begin{array}{c}\text { Accuracy } \\
\text { rate }\end{array}$ \\
\hline Cahill et al. ${ }^{10}$ & 1985 & 32 & $91.7 \%$ \\
Torres LF et al $^{11}$ & 1992 & 307 & $92.2 \%$ \\
\hline
\end{tabular}

\section{Eye Tumour}

Nine cases of retinoblastoma were diagnosed. The accuracy rate achieved on cytological diagnosis was $77.7 \%$. Our findings were in accordance with the observations of workers like Elgert and savala et al. (1996) who reported an accuracy rate of $75 \% .^{12}$ Histopathological findings in the nine cases studied, our series were also comparable to the finding reported by Eye Pathology Laboratory of Massachusetts Eye and Ear infirmary during period 1963-1976.

\begin{tabular}{lcc}
\hline $\begin{array}{l}\text { Histopathological } \\
\text { Findings }\end{array}$ & $\begin{array}{c}\text { \% Specimens } \\
\text { from MEEI }\end{array}$ & $\begin{array}{c}\text { \% Specimens } \\
\text { from our study }\end{array}$ \\
\hline Flexner Wintersteiner & 55 & 55.5 \\
rosettes & & \\
Fleurettes & 10 & 11.1 \\
Calcification & 78 & 66.6 \\
Endothelial hyperplasia & 53 & 22.2 \\
Necrosis & 51 & 77.7 \\
\hline
\end{tabular}

Gonadal Tumour

Seven cases of gonadal tumour were studied. An overall accuracy rate of $71.5 \%$ could be achieved in diagnosing gonadal tumours by fine needle cytology. Our results were comparable with results reported by Verma et al. (1989) who reported an accuracy rate of $75 \%-86 \%{ }^{13}$.

\section{Bone Tumour}

Two cases of osteosarcoma and one case of Ewing's sarcoma was studied. An overall accuracy rate of $66.6 \%$ was achieved; which was lower compared to the results of Walaas et al. (1990) who found an accuracy rate of $80 \%-95 \%{ }^{14}$.

\section{Neuroblastoma}

Two Cytosmears were diagnostic. While one showed features of plemomorphic round cells. Histopathology sections confirmed the cytological finding in all 3 cases. Thus, accuracy rate was $66.6 \%$ which was comparable to results of Silverman et al. who gave an accuracy rate of $57.1 \% 15$.

\section{CONCLUSION}

Out of 100 cases, satisfactory aspiration was obtained in 87 $(87 \%)$. Out of these, 87 cytosmears, the diagnosis was consistent with histopathology in 70 cases and not consistent in 17 cases. Therefore, an accuracy rate of $80.4 \%$ was obtained. Commonest malignancy was of kidney, mainly wilm's tumour (25\%). Lymphoma was second common (22\%) followed by soft tissue sarcoma (18\%). Brain tumour constituted $12 \%$, eye tumour $9 \%$, gonadal tumours $(5 \%)$, neuroblastoma, bone tumour and malignant teratoma accounted for $3 \%$ each. FNAC is feasible, rapid and inexpensive first approach in evaluation of cases of pediatric tumour but cytological diagnosis on FNA is not a substitute for the histological diagnosis on tissue section.

\section{REFERENCES}

1. Pratt CB Douglass EC, Green AA, Wrenn E, Champion J, Shipp $\mathrm{M}$. Effective cisplatin (DDP) based chemotherapy in the treatment of hepatoblastoma. Med Pediatr Oncol. 1985;13:187-90

2. Russell DS, Krayenbuhl $H$, Cairns $H$. The wet filmtechnique in the histological diagnosis of tumours: a rapid method. Am J Bacteriol1937; 45(3).

3. Taylor SR, Nunez C. Fine-needle aspiration biopsy in a pediatric population Report of 64 consecutive cases. Cancer. 1984;54:1449-53 4. Layfield LJ, Glasgow B, Ostrzega N, Reynolds CP. Fine needle aspiration cytology and the diagnosis of neoplasms in the pediatric age group. Diagn Cytopathol 1991; 7: 451-61.

5. Alasio L, Pilotti S, Rilke F et al. The role of fine needle aspiration in the assessment of renal masses. Acta Cytol .1988; 32:1-10.

6. Bezabih M. Cytological diagnosis of soft tissue tumours. Cytopathol. 2000;12:177-83.

7. Beckwith JB. Renal neoplasms of childhood. In: Sternberg SS, editor. Diagnostic Surgical Pathology. 2 nd ed. New York: Raven Press; 1994. p. 1741-66.

8. Nayar et al. Reliability and limitation of FNAC of lymphoadenopathy. Acta cytological,1990;777-779.

9. Dahl I, Akerman M, Angervall L. Ewing's sarcoma of bone: A correlative cytological and histological study of 14 cases. Acta Pathol Microbiol Immunol Scand. 1986;94:363-369.

10. Cahill EM, Hidvegi DF. Crush preparations of lesions of central nervous system. A useful adjunct to frozen section. Acta Cytol 1985;29(3):279-285.

11. Torres LF, Collaco LM. Smear technique for the intraoperative examination of nervous system lesions. Acta Cytol 1993;37(1):34-39.

12. Cangiarella JF, Cajigas A, Savala E, Elgert $P$, Slamovits $T L$, Suhrland MJ. Fine needle aspiration cytology of orbital masses. Acta Cytol 1996;40:1205-11.

13. Verma AK, Ram TR, Kapila K. Value of FNAC in the diagnosis of testicular neoplasms. Acta Cytol. 1989;33:631-4.

14. Walaas L, Kindblom LG. Light and electron microscopic examination of fine needle aspirates in the preoperative diagnosis of osteogenic tumors: A study of 21 osteosarcomas and 2 osteoblastomas. Diagn Cytopathol 1990; 6: 27-38

15. Silverman JF, Berns LA, Holbrook CT, Neil JSA, Joshi W. Fine needle aspiration cytology of primitive neuroectodermal tumors: $A$ report of these cases. ActaCytol 1992;36:541-50.

\section{Source of Support: Nil. Conflict of Interest: None Declared.}

Copyright: (c) the author(s) and publisher. IJMRP is an official publication of Ibn Sina Academy of Medieval Medicine \& Sciences, registered in 2001 under Indian Trusts Act, 1882.

This is an open access article distributed under the terms of the Creative Commons Attribution Non-commercial License, which permits unrestricted non-commercial use, distribution, and reproduction in any medium, provided the original work is properly cited.

Cite this article as: Mukesh Kumar Khinchi, Manish Kumar Singhal, Sangita Sehgal, Rachna Agrawal, Ashish Bagaria, Vinod Kumari, Alpana Jain, Vijayta Singh. A Cytopathological and Histopathological Correlation Study of Benign and Malignant Paediatric Age Group Tumour. Int J Med Res Prof. 2016; 2(6):172-76.

DOI:10.21276/ijmrp.2016.2.6.036 